\title{
Sharî‘a i praksis: fatwa, forbrug og feminisme
}

Af ph.d., seniorforsker Manni Crone, DIIS og ph.d. Brian Arly Jacobsen, ToRS, Københavns Universitet

Sharî‘a har de seneste år været genstand for en vis opmærksomhed. Ofte fremstilles Sharî‘a som et middelalderligt retssystem, der bl.a. indebærer straffemetoder som piskning eller stening. Det er en meget forenklet fremstilling. Sharî‘a (arabisk: "vej" eller "sti") henviser kort fortalt til den "vej" muslimer bør følge ifølge islamisk tradition. Sharî‘a er afledt af islams hellige tekst (koranen), og traditioner (hadith) indsamlet fra profeten Muhammeds liv. Der er forskellige fortolkninger af Sharî‘a, afhængigt af den tankegang (Madh'hab), og de særlige intellektuelle (Ulema), der er involveret i Sharî‘aprocessen. Islamisk retspraksis (Fiqh) fortolker og forfiner Sharî‘a ved at udvide gældende principper til at håndtere nye spørgsmål. Islamiske dommere (Qadi) benytter sig af Sharî‘a, men moderne anvendelse varierer fra land til land. Sharî‘a behandler mange aspekter af livet, herunder kriminalitet, politik, økonomi, banker, forretninger, kontrakter, familie, seksualitet, hygiejne og sociale spørgsmål.

I dette nummer af Tidsskrift for Islamforskning sætter vi fokus på, hvorledes Sharî‘a i øjeblikket forandrer sig og tilpasser sig en nutidig europæisk kontekst.

Karen-Lise Karman Johansen ser nærmere på The European Council for Fatwa and Research, der udsteder fatwaer om, hvordan Sharî‘a skal fortolkes i en europæisk kontekst. Artiklen viser, at Rådet på den ene side opfordrer til øget integration via medborgerskab og demokrati, og samtidig søger at institutionalisere islam gennem etableringen af islamiske voldgiftdomstole.

Halal-forbrug af kød, medicin, chokolade, kiks, shampo og lignende forbrugsvarer udgør i dag et kæmpe marked. Johan Fischer analyserer halalforbrug i London og viser, at halal ikke bare handler om at følge et religiøst påbud, men i lige så høj grad om sundhed, smag og pris. I dag kræver bevidste halal-forbrugere ikke bare religiøs, men også videnskabelig legitimering for at acceptere en vare som halal.

(C) Forfatteren og Tidsskrift for Islamforskning, ISSN 1901-9580, publiceret 15-03-2010 
Kvindelige selvmordsbombere har de seneste år været genstand for stor opmærksomhed. Louise Lund Liebman viser, hvorledes kvindelige palæstinensiske selvmordsbombere destabiliserer de patriarkalske normer, der kendetegner diskursen om den palæstinensiske nation. Derfor nedtoner offentlige fremstillinger ofte det kontroversielle ved deres handlinger og fremstiller dem enten som nationens "brude" eller ligefrem som ukønnede teenagere.

Endelig gennemgår Mark Sedgwick forskellige forståelser af salafisme og giver et bud på, hvordan salafisme kan forstås i dag. 